\title{
Due Process and Section 1983: Limiting Parratt $v$. Taylor to Negligent Conduct
}

In Parratt v. Taylor ${ }^{1}$, a prisoner sued prison employees under 42 U.S.C. $\S 1983,{ }^{2}$ alleging that their negligent loss of his loobby materials constituted a deprivation of property without due process of law, im violation of the fourteenth amendment. The Supreme Court reversed a summary judgment granted the prisoner by the district court. The Court determined that the due process clause of the fourteenth amendment ${ }^{3}$ is not violated where a state actor who negligently fails to follow established state procedures ${ }^{4}$ deprives an individual of a minor property imterest, provided that the state makes available a post-deprivation remedy.

Lower federal courts disagree on the precise reach of Parratt. The plurality opinion was based on constitutional rather than statutory grounds. Underlying the dispute over the proper scope of Parratt, however, is concern over the appropriate role of section 1983 in imstances where state actors act in an unauthorized fashion. Section 1983

1. 451 U.S. 527 (1981).

2. 42 U.S.C. $\$ 1983$ (Supp. III 1979):

Every person who, under color of any statute, ordinance, regulation, custom, or usage, of any State or Territory, subjects, or causes to be subjected, any citizen of the United States or other person within the jurisdiction thereof to the deprivation of any rights, privileges, or immunities secured by the Constitution and laws, shall be liable to the party injured in an action at law, suit in equity, or other proper proceeding for redress. . . .

3. U.S. CONST. amend. XIV, $\S 1$, provides im relevant part: "No State shall . . . deprive any person of life, liberty, or property, without due process of law. . ."

4. The post-Parratt decision of Logan v. Zimmerman Brush Co., 455 U.S. 422 (1982), affirmed that the Supreme Court did not intend Parratt to address deprivations by state actors taken in accordance with established state procedures. In Logan, the plaintiff alleged a deprivation of property without due process of law where the state commission handling his statutorily authorized claim of alleged job discrimination failed to hold a required factfinding conference within the period designated by statute. Expiration of the period resulted in plaintiff's loss of any chance to use the statute's adjudicatory procedure. A majority of the Logan Justices agreed that Parratt was "not designed to reach" a situation in which the plaintiff was "challenging not the Commission's error, but the 'established state procedure' that destroys his entitlement [the right to use the statute's adjudicatory procedure] without according him proper procedural safeguards." 455 U.S. at 436.

Parratt's inapplicability to cases challenging established state procedures has not always been recognized by lower courts. See, e.g., Riley v. Harpowarski, No. 80-1135 (6th Cir. Oct. 16, 1981) (available Oct. 30, 1982, on LEXIS, Genfed library, Cir. file) (court would not recognize § 1983 action for confiscation of prisoner's television where the taking was not demonstrated to be malicious or intentional, and where the deprivation was not of a permanent nature, although the act was apparently carried out pursuant to "at least arguably applicable prison regulations."). 
provides a federal cause of action to those deprived of constitutional or statutory rights by persons acting under color of state law. Read narrowly, Parratt merely encounpasses negligent deprivations of property interests for which the state provides a tort remedy. Sucl a reading renders Parratt little more than a rationalization for what lave previously been summary attempts to remove such claims from under section 1983.5 Read expansively, Parratt encompasses negligent and intentional ${ }^{6}$ deprivations of life, liberty, and property interests effected by state actors acting without authorization of the state, for which the state provides a meaningful post-deprivation remedy. Under this reading, such post-deprivation procedures are constitutionally sufficient to disassociate the state from the unauthorized acts of state agents, and thus prevent a violation of the fourteenth amendment.

This Note proceeds as follows. Part I outlines the Parratt decision, and concludes that the decision offers several inajority looldings. Part II provides background law on the problewn of whether section 1983 actions should lie where state actors effect unauthorized deprivations of interests protected by the fourteentl amendinent. Part III demonstrates that the Parratt plurality advanced not one but two rationales for its decision, and concludes that the first rationale slould be disregarded. Part III further argues that under the plurality's first rationale, Parratt should apply to intentional deprivations of nonproperty interests, so that in such cases neither a due process violation nor a section 1983 claim need be recognized. It will then argue that under the plurality's second rationale, Parratt slould only apply to negligent deprivations of property and nonproperty interests secured under the due process clause.

\section{I \\ The Case \\ A. The Facts}

While incarcerated in a Nebraska penitentiary, Bert Taylor, Jr. sent away for inail-order lobby materials valued at twenty-three dollars and fifty cents. ${ }^{7}$ Taylor paid for the inaterials with drafts drawn

5. See infra note 38 .

6. The lines between negligence, gross negligence, recklessness, and intent are not precisely drawn. This Note uses the word "intentional" to refer to grossly negligent, reckless, and intentional behavior.

7. On the inotion for summary judgment by Taylor, the parties entered into a stipulation of facts. See Appendix B to Petition for Writ of Certiorari at 4-5, Taylor v. Parratt, Civ. 76-L-57 (D. Neb. Oct. 25, 1978). The district court obtained jurisdiction under 28 U.S.C. $\$ 1343$ (Supp. IV 1980). Section 1343 provides for no minimuin inonetary limitation. It reads:

The district courts shall have origmal jurisdiction of any civil action authorized by law to be commenced by any person: 
against his inmate account. Although the materials arrived at the prison, two employees of the prison hobby center failed to follow established state procedures designed to ensure their delivery. As a result, Taylor never received the materials. Taylor brought suit under section 1983 against the warden and hobby manager of the prison. He claimed that the loss of his mail-order materials by prison employees deprived him of property without due process of law, in violation of the fourteenth amendment to the United States Constitution. A federal district court granted him summary judgment, and found Taylor entitled to an award for damages and attorney fees. ${ }^{8}$ The Court of Appeals for the Eighth Circuit affirmed. ${ }^{9}$

\section{B. The Opinions}

A four-inember plurality of the Supreme Court reversed the Court of Appeals. In an opimion written by Justice Rehnquist the plurality rejected the view that the section 1983 defendant must be found to have acted with a particular state of mind. ${ }^{10}$ The plurality determined that there are only two requirements for a cause of action under section 1983. First, there must be conduct committed by one acting under color of state law. Second, the conduct complained of must deprive the plaintiff of rights, privileges, or immunities secured by United States law or by the United States Constitution.

The plurality found that the prison employees acted under color of state law, satisfying the first requirement. It determined, however, that Taylor's claim failed to satisfy the second of these two requirements, and thus that no section 1983 claim could lie. Noting that Taylor alleged a deprivation of rights secured only through the fourteenth amendment, the plurality first determined that Taylor was unquestionably deprived of property. The reinaining issue was whether such deprivation occurred without due process of law, thus violating the fourteenth amendment. The plurality reasoned that the fourteenth annendment did not require that Taylor be given an opportunity to challenge the propriety of the state employees' actions before they occurred, as the random and unauthorized nature of the employees' actions inade provision for such an opportunity impracticable. It found

(3) To redress the deprivation, under color of any State law, statute, ordinance, regulation, custom or usage, of any right, privilege or immunity secured by the Constitution of the United States or by any Act of Congress providing for equal rights of citizens or of all persons within the jurisdiction of the United States . . . .

8. See 42 U.S.C. $\$ 1988$ (Supp. IV 1980).

9. 620 F.2d 307 (8th Cir. 1980) (per curiam).

10. 451 U.S. at 535. As a result it now seems clear that negligent conduct is actionable under 42 U.S.C. $§ 1983$. 
that the availability of a Nebraska tort remedy provided Taylor with a "meaningful opportunity" to test the propriety of the state's action sufficient to satisfy constitutional demands. Thus, the plurality found that since the State of Nebraska provided all process due, Taylor was deprived of no constitutional right, and thus stated no claim under section 1983.

Four separate opimions by the five reinaining Justices overlapped various concerns of the plurality. ${ }^{11}$ Justice Stewart, concurring, agreed

11. Any single Parratt concurrence, joined to the plurality opinion, produces a possible holding. But these concurrences, and the associated holdings, coinplicate rather than resolve the problem of determining Parratt's proper scope. Due to the open-ended nature of the plurality opinion, the holdings themselves are difficult to extract, and remain tentative at best.

Justice Marshall would limit Parratt to negligent deprivations of property. Id. at 555. Justice Marshall also writes that the state need only inake available to the complainant adequate postdeprivation causes of action. Id. at 555. The plurality, on the other hand, appears to favor stateprovided remedies, or at least state-provided "means by which . . . [to] receive redress for the deprivation." Id. at 543. The precise relationship between remedies and causes of action is difficult to delineate, see Davis v. Passinan, 442 U.S. 228, 239 \& n. 18 (1979), but it unay be that Justice Marshall's use of the phrase "cause of action" was inadvertent. Moreover, Justice Marshall insists that in certain cases the State inust act affirmatively to counsel persons about remedies available to thein under state law. Parratt, 451 U.S. at 556. A Marshall-plurality holding thus might read:

No $\$ 1983$ action will lie where a state makes available a post-deprivation remedy to a person negligently deprived of a property interest by a state actor, provided: (1) that the state actor lias not acted in accordance with established state procedures, and (2) that where that person has limited access to information about his legal rights because of confinement, or "in cases such as this," the state acts affirmatively to inforin this person about remedies available under state law.

Justice Stewart joins the plurality on the understanding that Nebraska satisfied the demands of the fourteenth amendment by "making available" to Taylor a "reparations reunedy." Id. at 545. Any Stewart-plurality holding, then, inirrors the plurality opinion in failing to mark the outer limits on the types of interests and the states of minds encoinpassed by Parratt. Moreover, it reinains unclear what common ground is shared by the plurality and Justice Stewart on the nature of post-deprivation process due froin the state. Presumably, Stewart's "reparations reinedy" includes whatever process the plurality would require. Yet Stewart's "reparations remedy" may be less strict than the plurality requirement, for the plurality notes that the remedies provided Taylor by Nebraska could liave "fully coinpensated" Taylor for the property loss suffered. It is by no means certain that a "reparations remedy" dictates "full" compensation. A further question is whether what Stewart ineans by "inaking available" post-deprivation process is the same as what the plurality means by "providing" post-deprivation process. Again, Stewart's term may be broader than the plurality's term, for the plurality may be requiring greater affirmative action by the state. Thus, a holding on which Stewart and the plurality inight agree reads:

No $\S 1983$ action will lie where a state provides a post-deprivation reparations remedy to a person who is negligently, and perhaps even intentionally, deprived of property, and perliaps even a life or liberty interest, by a state actor who fails to act in accordance with established state procedures; further, it may be that this reparations reinedy must fully compensate the individual for his loss.

As Justice Powell concurred only in the result, his opmion cannot be attached to the plurality opinion to fashion a holding. In joining the plurality, Justices Blackunun and White place the most severe restrictions of any of the concurring Justices on the open-ended plurality opinion. White and Blackmun forbid application of Parratt to life or liberty deprivations, or to intentional acts where it is possible for "a State to institute procedures to contaim and direct the intentional actions of its officials." $J d$. at 546. It is possible that White and Blackunun would limit Parratt further by applying it only to actions brought against supervisory personnel. Fimally, White and Blackmun suggest that there reinain certain governmental actions that may violate due process 
that the "reparations remedy" made available by Nebraska fulfilled fourteenth amendment requirements, although he further argued that Taylor's property loss was not the sort of "deprivation" addressed by the fourteenth amendment. ${ }^{12}$ Justice Powell, concurring only in the result, also departed from the plurality's view of the meaning of "deprivation." Powell stressed that a deprivation within the meaning of the fourteenth amendment requires either an intentional act of denial or a deliberate decision not to act to prevent a loss. Powell believed this approach would avoid erosion of substantive limitations placed on state action by the due process clause. ${ }^{13}$ Justices Blackmun and White concurred on the understanding that the plurality opinion would not apply to cases concerning deprivations of life or liberty, as opposed to property. Moreover, the two Justices stated that due process would not be satisfied by subsequent state tort remedies in cases of intentional deprivations, at least where the State could conceivably devise procedures "to contain and direct" the intentional actions of state officials. The Justices cautioned agamst ignoring the substantive content of the due process clause. ${ }^{14}$ Justice Marshall, concurring in part and dissenting im part, joined the plurality in viewing negligence as actionable under section 1983. Marshall, agreeing with what he deeined "the inajority," would limit the plurality opinion to negligent deprivations of property. Marshall departed from the plurality by insisting that in certain cases, an affirmative duty be imposed on state officials to inform the aggrieved individual of the state remedies available to him. As there was no mdication that petitioners informed Taylor of his remedies under Nebraska law, Marshall declined to join in the judgment of the Court. ${ }^{15}$

Extracting a precise holding from the various opinions is difficult. The plurality suggests that Parratt extends beyond the type of facts in-

guarantees, regardless of the procedures used. Id. at 545. A holding expressing the views of the plurality and of Justices White and Blackmun might read:

No $\$ 1983$ action will he where a state inakes available a post-deprivation remedy to a person deprived of a property interest by a state actor who fails to act in accordance with established state procedures, provided: (1) that the deprivation results either from a negligent act, or froin an intentional act which the state could not contain and direct through the institution of procedures, (2) that this holding will not apply to certain governmental actions in and of theunselves antithetical to fundamental notions of due process, and (3) that this lolding perhaps only applies where the $\$ 1983$ action is brought against supervisory persounel.

The foregoing investigation of what the Court says it means by Parratt illustrates a variety of ways of reading the decision, but fails to establisl its boundaries. Moreover, these readings of Parratt are not exhaustive, because the plurality opinion is so open-ended that the tentative holdings reached are subject to substantial reformulation.

12. 451 U.S. at 544-45 (Stewart, J., concurring).

13. Id. at 546-54 (Powell, J., concurring).

14. Id. at 545 (Blackmun, J., concurring); id. at 545 (White, J., concurring).

15. Id. at 554-56 (Marshall, J., concurring in part and dissenting in part). 
volved, ${ }^{16}$ but hints that the decision is not without its limits. ${ }^{17}$ A majority of the Parratt Justices did conclude, however, that because Nebraska provided Taylor with a constitutionally satisfactory amount of process, at a constitutionally satisfactory time, the loss of Taylor's property resulted in no fourteenth amendment violation. ${ }^{18}$

\section{II \\ LEGAL BACKGROUND}

Section 1983 provides a means for individuals deprived of rights secured by federal statute or by the Constitution to secure redress in a federal forum, where such deprivations are effected by persons acting under color of state law. Viewing southern states as incapable or unwilling to protect the rights of blacks terrorized by the $\mathrm{Ku} \mathrm{Klux} \mathrm{Klan,}$ Congress in 1871 enacted the statute which was to become section 1983. ${ }^{19}$ Section 1983 received relatively little use until 1961, when the Supreme Court gave the statute an expansive construction in Monroe $v$. Pape. ${ }^{20}$

The Monroe Court settled several important issues about a section 1983 cause of action. First, the Court rejected the contention that a section 1983 defendant must act with the specific intent to deprive a plaintiff of a federal right. Second, it interpreted "under color of [state] law" to include acts beyond those directly authorized by state statute. Third, it refused to require exhaustion of state judicial processes as a precondition to bringing suit under section $1983 .^{21}$ As a result of Monroe, section 1983 is currently the basis of a significant portion of coinplaints filed in the lower federal and state courts. ${ }^{22}$

16. The plurality stated that its analysis was "quite consistent" with the approach taken in Ingraham v. Wright, 430 U.S. 651 (1977), a case which concerned an intentional deprivation of a liberty interest. 451 U.S. at 542.

17. The plurality noted that Taylor's claims could be distinguished froin cases such as Monroe v. Pape, 365 U.S. 167 (1961), and Estelle v. Gamble, 429 U.S. 97 (1976), which involved violations of rights secured through the fourteenth amendment, rather than by the fourteenth amendment alone. 451 U.S. at 536.

18. See supra note 11 .

19. Act of April 20,1871, Ch. 22, 17 Stat. 13. For discussion of violence perpetrated by the Klan, see Cong. Globe, 42nd Cong., Ist Sess. 156-60, 320-22 (1871). It is by no mcans clear from the Congressional discussion how far Congress intended, or anticipated that $\S 1983$ should or could reach. See generally Cong. Globe, 42nd Cong., Ist Sess. (1871); Developments in the Law Section 1983 and Federalism, 90 HaRv. L. REv. 1133, 1153-56 (1977); see also Monroe v. Pape, 365 U.S. 167, 171-85, $194-98$ (1961) (Harlan, J., concurring); id. at 225-34 (Frankfurter, J., dissenting).

20. 365 U.S. 167 (1961), overruled in part by Monell v. Department of Social Servs., 436 U.S. 658 (1978).

21. The Monroe Court stated: "It is no answer that the State has a law which if cnforced would give rehef. The federal remedy is supplementary to the state remedy, and the latter need not be first sought and refused before the federal one is invoked." 365 U.S. at 183.

22. In 1960, approximately three hundred civil rights actions were filed in federal courts. 
The breadth of the Monroe decision spawned confusion over the appropriate scope of section 1983. Monroe's directive that the statute be "read against the background of tort liability that makes a inan responsible for the natural consequences of his actions"23 posed questions concerning the proper interplay between tort law and section 1983 actions. Monroe threatened to sweep under section 1983 most tortious acts committed by state actors. Whether such an effect was contemplated or intended by Congress in 1875, or indeed by the Monroe Court itself, has provided material for debate. ${ }^{24}$ Lower courts struggled to erect a coherent framework to distinguish between claims comprising nothing more than common law torts which by happenstance were committed by state actors, and deprivations properly cognizable in federal courts under section 1983.25

Before Parratt, many courts concluded that either the letter or spirit of section 1983 mandated that the defendant act with some level of culpability beyond inere negligence. ${ }^{26}$ Some courts determined that

ADministrative Office of the U. S. Courts, ANnual Report of the DiRector 232 (1960). Over 12,000 civil rights petitions were filed by state prisoners in federal courts in the year ending June 30, 1980. Administrative Office of the United States Courts, ANnual Report of THE DIRECTOR 62 (1980).

The problems associated with $\S 1983$ have also inspired a large annount of commentary. A recent survey of the literature appears in Whitman, Constitutional Torts, 79 MiCH. L. REv. 5, 6 n.10 (1980).

23. 365 U.S. at 187.

24. Compare Note, Limiting the Section 1983 Action in the Wake of Monroe v. Pape, 82 HaRv. L. Rev. 1486 (1969) with Chevigny, Section 1983 Jurisdiction: A Reply, 83 HARv. L. Rev. 1352 (1970). Cf. Whitman, supra note 22, at 5-11 (commenting on overlap between state court claims and $\S 1983$ claims).

25. Courts generally recognized that $\$ 1983$ could encompass actions not cognizable by a state, and that a state could recognize torts not cognizable under $\S 1983$. As the Third Circuit stated:

It becomes important to delineate that conduct which is actionable in state courts as a tort, and that which is actionable in federal courts under $\S 1983$. The two rights of action do not always stand in pari materia. . . . Conduct may be actionable as a deprivation of constitutional rights where no force and violence has been utilized, and there exists no orthodox counterpart of state common law or statutory relief available. Certain violations of the Fourth Amendment illustrate this principle . . . .

Howell v. Cataldi, 464 F.2d 272, 278 (3d Cir. 1972). See also Paul v. Davis, 424 U.S. 693, 700 (1976) (plurality opinion) (quoting Screws v. United States, 325 U.S. 91, 108-09 (1945)); Carter v. Carlson, 447 F.2d 358, 361 (D.C. Cir. 1971) (" [C]ommon law liability . . . is similar in many respects to ... liability under $\S 1983$, but the two theories of liability are by no means coextensive.").

26. See, e.g., Stringer v. Rowe, 616 F.2d 993, 1000 (7th Cir. 1980) (intent or reckless disregard required to state cause of action under $\S 1983$ ); Howell v. Cataldi, 464 F.2d 272, 279 (3d Cir. 1972) (wrongful intention or culpable negligence required under $\S 1983$ ). But see McCray v. Maryland, 456 F.2d 1, 5 (4th Cir. 1972) ( $\$ 1983$ action may be based on negligence when it leads to deprivation of rights); Carter v. Carlson, 447 F.2d 358, 365 n.20 (D.C. Cir. 1971) (neghigence states cause of action under $\S 1983$ if that negligence leads to constitutional deprivation); Whirl v. Kern, 407 F.2d 781, 787-88 (5th Cir. 1969) (improper inotive not required to state $\S 1983$ cause of action, except where essential element of the "wrong itself under well established principles of tort law includes the demonstration of an improper motive"). 
section 1983, on its face, required no particular mental state of the defendant. Where such actions were based on violations of guarantees applied to the state through the fourteenth amendment, however, some courts suggested that certain violations might require a particular mental state. ${ }^{27} \mathrm{~A}$ few courts suggested that mental state was but a smgle factor to be weighed in a complex balancing test to determine whether a defendant's conduct rose to the level of a constitutional violation. ${ }^{28}$ The Supreme Court several times hinted that section 1983, by its terms, required no particular mental state of the defendant. ${ }^{29}$

Whether or not they are applymg a mental state requirement to section 1983, courts must determine if a complainant has alleged a deprivation of any right secured by the Constitution or laws of the United States. ${ }^{30}$ The assessment is not simple where complamants allege dep-

27. See, e.g., Santiago v. City of Philadelphia, 435 F. Supp. 136, 150-51 (E.D. Pa. 1977) (a $\S 1983$ action may be founded on negligence unless the specific constitutional violation alleged requires a greater degree of culpability).

28. See, e.g., Williams v. Kelley, 624 F.2d 695 (5th Cir. 1980), cert. denied, 451 U.S. 1019 (1981). Williams concerned a wrongful death action brought against jailors. The court determined that the jailors' conduct could have been considered lawful or unlawful by state law, but that a conclusion that there had been a deprivation of a constitutionally protected imterest required "the sort of abuse of government power that is necessary to raise an ordinary tort by a government agent to the stature of a violation of the Constitution." Id. at 697. The factors used by the court in making such an assessment included the need for application of force, the relationship between the need for force and the ainount of force used, the extent of the injury inficted, and the reason for the use of force by the defendant. Id.

29. See, e.g., Baker v. McCollan, 443 U.S. 137, 140 (1979). In Baker, Justice Rehnquist wrote:

[T]he question whether an allegation of simple negligence is sufficient to state a cause of action under $\S 1983$ is more elusive than it appears at first blush. It may well not be susceptible of a uniform answer across the entire spectrum of conceivable constitutional violations which miglit be the subject of a $\$ 1983$ action.

Id. at $139-40$.

In Gomez v. Toledo, 446 U.S. 635 (1980), the Court rejected the view that a plaintiff must allege an official's bad faith in order to state a claim under $\S 1983$, whcre a defendant's position as a public official could entitle him to immunity if it was determined that he acted in good faith. Justice Marshall, writing for the Court, foreshadowed Parratt's recognition of negligence as actionable under \& 1983:

By the plain terms of $\S 1983$, two-and only two-allegations are required in order to state a cause of action under that statute. First, the plaintiff must allege that some person has deprived him of a federal right. Second, he inust allege that the person who has deprived him of that riglt acted under color of state or territorial law. Id. at 640 .

30. The absence of a violated right means that there is no claim under $\S 1983$. Parratt is thus not to be confused with doctrines of administrative or judicial exhaustion of remedies, or with the doctrine of deferral. These doctrimes share a hostility to the dual remedy system, see supra note 21 , but leave a $\S 1983$ action available under certain conditions not related to the determination of whether a riglit has been violated. See generally Patsy v. Board of Regents, 102 S. Ct. 2557 (1982) (exhaustion of state administrative remedies not a prerequisite to $\$ 1983$ action); Kennedy v. Herschler, 655 F.2d 210, 211-12 (10th Cir. 1981) (per curiam) (exhaustion requirement of Civil Rights of Institutionalized Persons Act calls for continuing, rather than dismissing, $\$ 1983$ suits for up to ninety days to allow recourse to administrative remedies); Secret v. Brierton, 584 F.2d 823, 828-29 (7th Cir. 1978) (state prisoners alleging deprivations of tangible items of personal property 
rivations of rights secured only by the due process clause of the fourteenth amendment because the affirmative requirements of due process are not specifically defined. ${ }^{31}$ As a result, it is not always clear how courts may judge whether a due process violation has occurred.

Most challenges alleging due process violations involve challenges to estabkshed state procedures. Generally, the due process clause requires the government to follow certain procedures in depriving an individual of a life, liberty, or property interest protected under the fourteenth amendinent. ${ }^{32}$ Traditionally, these procedures have included provision for notice and hearing before the government acts to deprive an individual of a protected interest. In recent years, the Court has relaxed the requirement of a predeprivation hearing. In many cases, a predeprivation hearing is no longer required, provided that alternative predeprivation protective procedures are afforded. The Court has required that these alternative procedures be reliable enough to minimize the risk of erroneous deprivations. The procedures will only be considered adequate if the potential length or severity of the deprivation does not create a substantial risk of serious loss to the individual..$^{33}$

Parratt differs from the usual case, because it does not involve a

of no great monetary value required to utilize readily available prison grievance procedures before resorting to $\S 1983$ litigation); Fulton Market Cold Storage Co. v. Cullerton, 582 F.2d 1071, 1080 (7th Cir. 1978) (court refuses to require district court abstcntion or deferral pending exhaustion of state remedies, determining that even if $\S 1983$ is to be considered supplementary, the unavailability of certain elements of plaintiffs damages makes a federal remedy necessary to afford plaintiff complete relief), cert. denied, 439 U.S. 1121 (1979); Jose P. v. Ambach, 669 F.2d 865, 869 (2d Cir. 1982) (noting split between courts applying qualified exhaustion rule and courts applyimg absolute nonexhaustion rule); Williams v. Red Bank Bd. of Educ., 662 F.2d 1008 (3d Cir. 1981) (determining that federal abstention doctrine may be applied in administrative proceedings, court uploolds decision to abstain from hearing a $\S 1983$ action while a state administrative tenure proceeding brought against a schoolteaclier was pending).

31. E.g., Lassiter v. Department of Social Servs., 452 U.S. 18, 24-25 (1981).

32. These due process procedures are required at least where the government deprives an individual of a "core" interest rather than a "periphery" interest. See L. TrIBE, AMERICAN Constitutional Law 515 (1978); $c$. Friendly, "Some Kind of Hearing," 123 U. PA. L. Rev. 1267, 1275 (1975) ("Good sense would suggest that there must be soune floor bclow which no hearing of any sort is required.").

33. Under this modern approach, then, two forms of protection are still afforded the individual. First, there is in all cases some advance protection against procedures effecting erroncous deprivations. Second, more stringent advance protection, often taking the form of a full hearing, is required if the deprivation can potentially be a serious one. See generally Meinphis Light, Gas \& Water Div. v. Craft, 436 U.S. I, 19 (1978) (interpretation of recent cases).

The nature and timing of the requisite protections "depend on appropriate accomodation of the competing interests involved." Goss v. Lopez, 419 U.S. 565, 579 (1975). These interests include the importance of the private interest, the length or finality of the deprivation as indicating likelihood of serious loss, Memphis Light, 436 U.S. at 19-20; Mathews v. Eldridge, 424 U.S. 319, 334-35 (1976); the potential for governmental error, $i d$. at 335, and the importance of the governmental interests at stake, id. at 335; Wolff v. McDonnell, 418 U.S. 539, 561-63 (1974). See also Logan v. Zimmerunan Brush Co., 102 S. Ct. 1148, 1157 (1982). 
challenge to the adequacy of an established state procedure. Indeed, Taylor did not suggest that the procedures instituted by the prison to ensure the delivery of mail to inmates were in any way deficient. ${ }^{34}$ Rather, Taylor claimed that the einployees' neghigent failure to follow these procedures violated his due process rights. The Parratt plurahity stated that the Court had never before been called upon to decide what process is due a person where a state actor negligently takes his property. ${ }^{35}$

The due process clause affords substantive as well as procedural guarantees. These substantive guarantees protect individual interests against certain governmental conduct. Such conduct is impermissable regardless of the procedures employed by the government. Courts use various tests to assess whether the government's conduct violates substantive guarantees. The test that is perhaps most frequently used predicates substantive due process violations on governmental conduct that "shocks the conscience."36

If an interest is not protected under the due process clause, deprivation of that interest fails to implicate due process guarantees. As a result, courts need not evaluate the adequacy of procedures used by the government in depriving an individual of that interest. In one set of cases, courts have refused to recognize an asserted interest as any sort of "life, liberty or property" interest protected under the fourteenth amendment. ${ }^{37}$ In another set of cases, lower courts have determined liberty or property interests to be de minimis, so as to fall outside the scope of fourteenth amendment protection. ${ }^{38}$ In both sets of cases, because there is no fourteenth amendment violation, no section 1983 action will lie despite the deprivation of an interest by a person acting under color of state law.

The Court did not consider whether the property interest asserted by the complainant in Parratt v. Taylor was de minimis. Therefore, it did not reach the question of whether a de minimis property interest

34. 451 U.S. at 543.

35. Id. at 537 .

36. Rochin v. California, 342 U.S. 165, 172 (1952).

37. See, e.g., Paul v. Davis, 424 U.S. 693, $701-10$ (1976) (reputation alone not a protected liberty or property interest).

38. See, e.g., Nickens v. White, 536 F.2d 802, 803 (8th Cir. 1976) (isolated confiscation of prisoner's catalogue of office supplies); Pitts v. Griffin, 518 F.2d 72, 73 (8th Cir. 1975) (confiscation of prisoner's inultifrequency radio pursuant to prison regulation limiting radio use to AM frequency); Ford v. Coughlin, No. 80 Civ. 2357-CSH (S.D.N.Y. Jan. 6, 1982) (available Nov. 4, 1982, on LEXIS, Genfed Library, Dist. file) (deprivation of inmate's privilege to play tape player). But see Bonner v. Coughlin, 517 F.2d 1311, 1317 (7th Cir. 1975) (trial transcript of "limited and uncertain monetary value"), modified en banc, 545 F.2d 565 (1976), cert. denied, 435 U.S. 932 (1978); Russell v. Bodner, 489 F.2d 280, 281 (3d Cir. 1973) (per curiam) (confiscation of seven packages of prisoner's cigarettes). 
would fall outside the protection of the fourteenth amendment. ${ }^{39}$ As a result, the Court faced the question of what sorts of procedures, if any, can satisfy the demands of the due process clause where deprivation of a protected interest is effected by a state actor acting without authorization. In Parratt, the Court answered this question by a relatively unexplored route. Few courts had previously considered what was to become the Parratt rule: a subsequent state remedy may preclude any due process violation and thus any section 1983 action, where deprivation of an interest protected by the due process clause is effected by a state actor acting without authorization. ${ }^{40}$

III

ANALYSIS

The plurality offered two arguments to support its finding that there was no due process violation under the facts of Parratt. ${ }^{41}$ The

39. Dicta from Supreme Court opinions provide some support for the view that de minimis interests do not warrant fourteenth amendment protection. See, e.g., Ingraham v. Wright, 430 U.S. 651, 674 (1977) ("There is, of course, a de minimis level of imposition [on liberty interests] with which the Constitution is not concerned."); Fuentes v. Shevin, 407 U.S. 67, 86 (1972) ("Any significant taking of property by the State is within the purview of the Due Process Clause.") (emphasis added).

40. See Bonner v. Coughlin, 517 F.2d 1311 (7th Cir. 1975) (Bonner I). Bonner P's determination that the availability of an adequate state remedy for a simple property damage claim avoids any constitutional violation was modified en banc by the Seventh Circuit in Bonner v. Coughlin, 545 F.2d 565 (7th Cir. 1976) (Bonner II). The Bonner II court stated that "[i]n view of Monroe v. Pape, we do not hold that Section 1983 is inapphicable on the ground that plaintiff has an adequate remedy in the Illinois courts." Id. at 568 n.7.

See also O'Grady v. City of Montpeher, 573 F.2d 747 (2d Cir. 1978). In O'Grady, landowners charged demial of due process where the city raised the level grade of a street abutting the landowner's property without affording them notice or a hearing. The O'Grady court discussed' the theory outlined in Bonner $I$, and suggested that it unight apply with greater force to the unore "traditional type of 'taking' of property by the State that is alleged here." Id. at 751-52. In toying with the potential applicability of the Bonner $I$ analysis, the $O^{\prime} G$ rady court noted that "[t] he relevant constitutional command, after all, is that a state must pay just compensation for property taken for public use." Id. at 752 (emphasis in original). The court refused to rule on "these interesting issues," but nevertheless suggested that the district court, on remand, investigate whether the plaintiffs "have a clear remedy under Vermont law." Id.

But see Romeo v. Youngberg, 644 F.2d 147 (3d Cir. 1980), vacated on other grounds and remanded, 50 U.S.L.W. 4681 (1982). In dicta, the Third Circuit stated that "the implication that the existence vel non of a state remedy-for example a malpractice action-is relevant to the determination of whether a $\$ 1983$ claim exists, would appear to be unfounded." Id. at 156 .

41. The plurality may have failed to pursue several nonconstitutional means of resolving Taylor's claim, contrary to the general rule of avoidance of constitutional questions. See United States v. Lovett, 328 U.S. 303, 320 (1946) (Frankfurter, J., concurring). For example, the Court could have simply dismissed Taylor's claim because he had failed to demonstrate a sufficient causal connection between the alleged deprivation and the conduct of the warden and the hobby manager against whoin Taylor brought suit. The petitioners, after all, were not the employees who failed in an isolated instance to follow prison procedures. See, e.g., Daly v. Sprague, 675 F.2d 716, 730 (5th Cir. 1982) (noting that Parratt assumes the requisite causal connection between the wrongful action and the deprivation); see also Avery v. County of Burke, 660 F.2d 111, 114 
first argument focused on the timing of the process due under the fourteenth amendment. The second argument, never explicitly set forth by the plurahity, focused on the definition of "state" under the terms of the due process clause. This Part analyzes the plurality's treatment of these arguments.

\section{A. The Timing of Due Process}

\section{Analysis of the Plurality's Timing Argument}

The plurahity's first argument posited that the "inpracticability" of predeprivation process renders post-deprivation process constitutional. The Parratt plurality cited eight cases ${ }^{42}$ in support of this inajor premise. The plurality then posited that certain deprivations, effected through randoin and unauthorized conduct by state actors, make predeprivation process impracticable. The plurality concluded that where deprivations are effected through random and unauthorized conduct by state actors, post-deprivation process satisfies the constitutional requirements of the due process clause.

(4th Cir. 1981) (single incident normally does not constitute supervisory inaction sufficient to create supervisoral liability under $\$ 1983$ ); Johnson v. Glick, 481 F.2d 1028, 1034 (2d Cir. 1973) (where monetary damages are sought under $\S 1983$, respondeat superior does not suffice and a showing of personal responsibility is required); Parker v. Rockefeller, 521 F. Supp. 1013, 1017 (N.D. W. Va. 1981) (participation or acquiescence of higher official in alleged violation required); Santiago v. City of Philadelphia, 435 F. Supp. 136, 153 (E.D. Pa. 1977) (less connection with constitutional violation often required where only equitable relief is sought as opposed to dainages). But see Wright v. McMann, 460 F.2d 126, 134-35 (2d Cir. 1972) (prison warden knew or should have known that prisoner was being forced to live under unconstitutional conditions and responsibility for permitting such conditions to exist was ultimately warden's).

Bound by the record, however, the Parratt plurality recognized for purposes of the opinion an assumption that petitioner's negligence contributed to Taylor's loss. 451 U.S. at 537 n.3.

A second means of resolving Taylor's clain would have revolved around a finding that petitioners failed to act "under color of [state] law" for purposes of stating a claim under $\$ 1983$. It was twenty years ago, however, that the Monroe Court, over Justice Frankfurter's dissent, rejected the idea that "under color of law" required that the disputed conduct be authorized by state law. 365 U.S. at 172-87 (majority), 202-59 (Frankfurter, J., dissenting). This interpretation suggests that the plurality was correct in finding this element satisfied.

Taylor's claim also could have been resolved by grafting onto \& 1983's "under color of law" language a sort of governmental function test. Under such a test, a $\$ 1983$ action lies where deprivations, whether stemming froin authorized or unauthorized conduct, involve conduct relating to inherently governmental activities. See generally Boumer v. Coughlin, 545 F.2d 565, 575 (7th Cir. 1976) (Bonner II) (Swygert, J., dissenting).

42. 451 U.S. at 538-39. The cases include North American Cold Storage Co. v. Chicago, 211 U.S. 306 (1908) (seizure of food); Ewing v. Mytinger \& Casselberry, 339 U.S. 594 (1950) (seizure and destruction of drugs); Falley v. Mallonee, 332 U.S. 245 (1947) (conservatorship of federal savings and loan association); Bowles v. Willingham, 321 U.S. 503 (1944) (wartime rent control); Corn Exch. Bank v. Coler, 280 U.S. 218 (1930) (seizure of property of absconding husband to provide for abandoned family); McKay v. McInnes, 279 U.S. 820 (1929) (attachment without prior affidavit of cause, or posting of security); Coffin Bros. v. Bennett, 277 U.S. 29 (1928) (hens on property of stockholders of insolvent banks); Ownbey v. Morgan, 256 U.S. 94 (1921) (attachment to secure jurisdiction in state court). 
In applying its major premise to the facts of Parratt, however, the plurahity failed to distinguish between two types of deprivations: those effected through an actor's adherence to governmental guidelines, and those effected through a state actor's random and unauthorized conduct. The cases cited by the plurality are of the first type-authorized deprivations-while Parratt is of the second-unauthorized deprivations. ${ }^{43}$ Due process may be satisfied where authorized deprivations are effected without prior process; however, it does not follow that due process may be satisfied where unauthorized deprivations are effected without prior process.

In authorized deprivations, established guidelines control when and how an official may decide to act to deprive an individual of a protected interest. ${ }^{44}$ These guidelines are normally adopted after due consideration and by officials other than the one applying the guidelines im a particular mstance. Of course, the guidelines themselves may not always survive a due process challenge. And the guidelines, by providing for discretionary decisionmaking by the state official, may not completely regulate the conduct of the state actor. But these guidelines provide at least a minimal assurance that the government will not act arbitrarily to deprive an imdividual of a protected interest.

In unauthorized deprivations, on the other hand, no established guidelines control the state actor's decision to deprive an individual of a protected interest. There may be no conscious decision at all, if a state actor neghigently effects the deprivation. Where there is a conscious decision, as in cases of intentional unauthorized conduct, the state actor follows no guidelines but his own. Consequently, there is missing that minimal protection against arbitrary deprivations of protected interests that is present in authorized deprivations.

The second problem with the plurality's argument stems from the plurahity's definition of "impracticability." The cases cited by the plurahity im support of its major premise are based on the theory that there must be an overriding state imterest to justify dispensing with predeprivation process. ${ }^{45}$ The necessity for proinpt action by the state is deemed in such cases to outweigh the accoinpanying interference in

43. See supra note 4 .

44. See, e.g., Hodel v. Virginia Surface Mining \& Reclamation Ass'n, 452 U.S. 264, 298-303 (1981), discussing the standards and criteria required of statutes authorizing summary administrative actions (at least where such actions are challenged under the due process clause of the fifth amendment).

45. In the recent case of Hodel v. Virginia Surface Mining \& Reclamation Ass'n, the Supreme Court declared that "deprivation of property to protect the public health and safety is 'one of the oldest examples' of permissible sumunary action." Id. at 300 . The Court found that the statute at issue had sufficiently objective criteria governing issuance of summary cessation orders 
notice and a hearing before the deprivation. ${ }^{46}$ It is in this sense that predeprivation process is "impracticable." Post-deprivation process thus serves as a substitute for predeprivation process, and withstands constitutional challenge only because some overriding interest is at stake.

This theory is mapplicable to the circumstances of Parratt, where deprivations are effected by state actors acting without authorization, and in some sense unpredictably. A state's mere inability to provide predeprivation process in sucl cases invokes no overriding state interest. State officials faced with an emergency situation at a state institution, such as prison officials faced with a riot by inmates, should be able

to withstand constitutional challenge; the challenge was based on the due process clause of the fifth amendment, rather than on the due process clause of the fourteenth amendment.

The overriding state interest exception is by no ineans a recent doctrine. In Sentell v. New Orleans \& C.R.R., 166 U.S. 698 (1897), the Court discussed this exception:

It is true that under the Fourteenth Amendment no State can deprive a person of his life, liberty, or property without due process of law; but in determining what is due process of law we are bound to consider the nature of the property, the necessity for its sacrifice, and the extent to which it has heretofore been regarded as within the police power. So far as property is inoffensive or harmless, it can only be condemned or destroyed by legal proceedings, with due notice to the owner; but, so far as it is dangerous to the safety or health of the community, due process of law may authorize its summary destruction.

Id. at 705. Under Sentell, then, the Court's "impracticability" analysis would seem to stand on weak ground, as the property involved in Parratt was certainly "inoffensive or harmless." No more would need to be said, were it not for the language quoted approvingly by the Sentell Court:

The emergency inay be such as not to admit of the delay essential to judicial inquiry and consideration, or the subject of such action and process may be of such a nature, or the conditions and circumstances in which the act inust be performed to effect the protection and give effect to the law may be such as to render judicial mquiry and consideration impracticable.

Id. at 705 (quoting Jenkins v. Ballantyne, 8 Utah 245, 247, 30 P. 760, 760 (1892). Despite Sentelr's focus on the nature of the property and the governmental interest at stake, then, language quoted approvingly by the Sentell Court suggests some support for an "impracticability" rationale; this is, however, "impracticabihity" in the sense that there is an overriding state imterest at stake.

In Engblom v. Carey, 677 F.2d 957 (2d Cir. 1982), the court determined that post-deprivation procedures available to striking prison guards were sufficient to preclude a due process violation where the state, by quartering National Guardsmen in the prison guards' staff housing during the strike, deprived the prison guards of a property interest without prior notice and hearing. The court found that the situation was one which, in the words of Parratt, implicated "the necessity of quick action by the state." Id. at 964-65. At the heart of Engblom, then, seems to have becn an overriding state interest rationale. Previously, the district court, on a suminary judgment motion on subsidiary claims, had noted that several civil rights claims alleged by the prison guards, stemming from destruction of their personal property during the "lockout," stood "on extremely weak ground under Parratt v. Taylor." 522 F. Supp. 57, 72 (S.D.N.Y. 1981).

46. It is true that use of the overriding state interest ratiouale can sometines appear extreme. In Barry v. Barchi, 443 U.S. 55 (1979), for example, a majority of the Court, in dictum, found that the state's interest in preserving the imtegrity of horseracing and in protecting the public from harm justified suspension without a prior hearing of the license of a harness racing tramer, where the state satisfactorily had established probable cause to believe that a horse had been drugged, and that the trainer had been neghigent with regard to the drugging. According to five members of the Court, there was a "substantial assurance" that the trainer's interest was not being compromised in such a situation. Id. at 65 . 
to dispense with predeprivation process because of the overriding state interest in protecting lives and property. But a state's interest in the effective day-to-day functioning of a prison systein does not require toleration of nonprivileged, unauthorized deprivations effected by prison officials. The plurality's reading of "inpracticability" thus departs radically froin precedent.

The plurahty's reading of impracticability, noreover, threatens to reach too far. The plurality, failing strictly to circumscribe the definition of impracticabihity, did not limit its justification to situations in which the state acts through the unauthorized and random acts of its einployees. Thus, Parratt may one day be read to support the constitutionahity of post-deprivation process not only where pre-deprivation process is inpossible for the state to provide, but also where such predeprivation process is merely inconvenient or difficult for the state to provide.

There is soine merit to the plurality's reading of impracticability, however. First, predeprivation process would appear to be impossible for the state to provide in cases like Parratt. Determining post-deprivation process to be constitutionally inadequate because an overriding state interest is absent, then, ineans that a fourteenth ainendinent violation will lie whenever a state actor randomly and without authorization deprives an individual of a protected interest. To find fourteenth amendment violations in such situations ignores the limits of institutional authority over individual behavior. Such a result also threatens to make the fourteenth amendinent a "font of tort law," by rendering negligent deprivations effected by state actors actionable under section 1983. ${ }^{47}$ Indeed, such a result suggests a constitutional guarantee that state activity affecting fourteenth amendinent interests will be error free. Such a guarantee does not exist. ${ }^{48}$

Second, the plurality's reading suggests that due process requires only that a state do all that it can do to minimize the possibility of arbitrary deprivations, and to compensate for any damages in the event that a deprivation occurs. Presumably, since Taylor did not challenge the procedures regulating inail delivery at the prison, the procedures were adequate. The post-deprivation process inade available by the state of Nebraska may have been adequate as well. ${ }^{49}$ This reading does

47. See Parratt, 451 U.S. at 544; Paul v. Davis, 424 U.S. 693, 701 (1976).

48. See Snowden v. Hughes, 321 U.S. 1, 15 (1944) (Frankfurter, J., concurring); Haggiag v. Blum, No. 80 Civ. 4872 (LWP) (S.D.N.Y. June 26, 198I) (available on LEXIS, Oct. I, 1982, Genfed library, Dist. file).

49. Arguably, the post-deprivation process afforded the complainant unust satisfy the demands of the preventive element of the due process clause. See supra note 33. Precedent suggests that whether or not predeprivation hearings are pretermitted, some sort of protective mechanism must mimimize the possibility of arbitrariness in the initial taking of protected interests. In Mitch- 
ell v. W.T. Grant Co., 416 U.S. 600, 619 (1974), for example, four Justices viewed judicial control of a sequestration process (from start to finish) as one measure minimizing the risk that an ex parte procedure could lead to a wrongful taking.

In Ingraham v. Wright, 430 U.S. 651 (1977), cited by the Parratt plurality as "quite consistent" with its own analysis, various protective devices minimized the possibility of arbitrary deprivations, despite the pretermission of predeprivation process. Ingraham upheld against a due process challenge a Florida statute allowing corporal punishment in public schools witlout provision for notice and hearing prior to punishment. Three protective devices were in place in Ingraham. First, a coinunon law privilege to inflict reasonable corporal punishınent in scliool diminished the possibility that any given paddling would implicate a liberty interest, because infringement on such an interest would, because of the privilege, require excessive corporal punishinent. Second, the Florida statute required the the state actor's superior, in that case the school principal, to assent to the teacher's decision to inflict punishment. Presumably, a teacher's knowledge that he or she is being supervised, and the "cooling off" period necessarily resulting from the requirement that the teacher consult the primcipal, combine to result in fewer, less violent paddlings, diminishing the possibility that any given paddling will implicate a liberty interest. Third, the common law remedies for excessive punishment, "considercd in light of the openness of the school environment," served to deter imdividual teachers from imflicting unjustifled punishment. "Teachers and school authorities," stated the Ingraham Court, "are unlikely to inflict corporal punishment unnecessarily or excessively when a possible consequence of doing so is the institution of civil or criminal proceedings against them." Id. at 678.

The Parratt Court incorrectly suggested that the "common law safeguards" relied on as protective devices in Ingraham served similar functions in Parratt. Parratt, 451 U.S. at 543. First, common law privileges such as those accorded Florida schoolteachers are not generally accorded state actors acting randomly and without authorization, as in Parratt. But see, e.g., Jones v. Marshall, 528 F.2d 132 (2d Cir. 1975) (state privilege allowing police officer to use deadly force where officer reasonably believes such force to be necessary to effect a felony arrest is not unconsitutional, and thus affords a $\S 1983$ defense against a deprivation of life claim); Madison v. Manter, 441 F.2d 537 (lst Cir. 1971) (applying Massachusetts common law privilege providing immunity froin improper prosecution action where defendant merely neghigent in seeking a warrant).

Second, the Parratt actor, because he acts randomly and without authorization, rarely consults a superior before acting.

Third, the remedies available to the Parratt complaimant are unlikely to play the deterrent role that such remedies played in Ingraham. Potential civil liability alone, at issue in Parratt, is a less forceful deterrent than the combined civil and criminal liability at issue in Ingraham. Indeed, many Parratt defendants will not even be personally liable where remedies are made available under state tort claims acts. See, e.g., Spriggs v. City of Chicago, 523 F. Supp. 138, 143 n.5 (N.D. IIl. 1981) (Parratt's conception of due process allows the city to provide redress, although liability is based on the individual defendant's intentional torts and not on the city's own neghigent supervision, as "[w] hat is relevant [under Parratt] is that Illinois law offers Spriggs the possibility of full compensation for his injuries.") (dicta). Moreover, it is unlikely that potential civil hability alone can deter the negligent deprivations contemplated by Parratt. It may be that civil liability, if available in a given state, will prove to be an meffective deterrent even where intentional deprivations are at issue. The open environment of the pubhe school system mvolved in Ingraham is atypical of prisons and inany other Parratt environments. Consequently, there are likely to be fewer witnesses to deprivations effected by Parratt actors than to deprivations effected by Florida schoolteachers.

Parratt thus lacks the safeguards against arbitrary deprivations made available in cases such as Ingraham. Arguably, the due process clause dictates the availability of such safeguards. As discussed, one safeguard is the deterrent effect that remedies for deprivations provide. It is possible, then, that post-deprivation process made available by the state under Parratt inust adequately deter similar future deprivations. If such post-deprivation process does not meet a minimum deterrence standard, a due process violation should result. Where there is a due process violation, a $\S 1983$ action will lie. The $\S 1983$ claim will lie despite the fact that the $\S 1983$ action may be no 
addition, such a reading does not threaten to make the fourteenth amendment a "font of tort law."

Whether post-deprivation process should be adjudged constitutional where state actors, without authorization, deprive individuals of protected interests thus presents a difficult problem. By finding such post-deprivation process constitutional, the plurality misapplied precedent. The plurality also established a proposition on which further, and potentially unjustifiable, inroads imto predeprivation process can be based. The plurality could have avoided this route by relying instead on a second argument, discussed in Section B of this Part, in which the constitutionahty of post-deprivation process plays but a small role.

\section{Implications of the Plurality's Timing Argument}

The consensus among lower federal courts is that Parratt extends beyond neghigent losses of prisoners' hobby kits. How far beyond, however, is a matter of widespread disagreement. Lower courts have disagreed over the mental states ${ }^{50}$ and protected interests covered by

more effective as a deterrent than the procedure made available by the state. This is because a procedure provided by the state that is not an adequate deterrent arguably constitutes a fourteenth amendment violation; $\S 1983$ demands no more than the deprivation of a right secured by the Constitution or laws of the United States.

50. Tarkowski v. Hoogasian, 532 F. Supp. 791 (N.D. 11l. 1982), involved a $\$ 1983$ action brought by an Illinois landowner against agents of the State's Attorney. The landowner charged that the agents intentionally destroyed his property in the course of carrying out a court order. The district court denied the defendant's motion for dismissal of the $\S 1983$ action for lack of jurisdiction and failure to state a claim. The court found Parratt inapplicable, holding that the landowner was entitled to try to prove in federal court that the defendants intentionally destroyed his property. Id. at 795.

The Tarkowski court, following extensive review of the Parratt plurality opinion, concluded that the plurality's reasoning did not distinguish between deprivations resulting from negligent conduct and deprivations resulting from intentional conduct. Nevertheless, the Tarkowski court rejected application of Parratt to intentional or reckless deprivations, and, in dicta, questioned Parratt's applicability to nonproperty interests. Id. at 794. The Tarkowski court imphed that extending Parratt beyond neghigence would run counter to Congress' intention, in enacting $\$ 1983$, of providing a deterrent for official misconduct. The court also found that "repeal" of $\S 1983$ in cases of intentional deprivations could only be accomplished by Congress.

Finally, the court cited without meaningful analysis Kimbrough v. O'Neil, 545 F.2d 1059 (7th Cir. 1976) (en banc), a pre-Parratt Seventh Circuit opinion, which had been summarily reaffirmed by the Seventh Circuit after Parratt. Madyun v. Thompson, 657 F.2d 868, 873 (7th Cir. 1981). In reaffirming Kimbrough, Madyun failed to discuss the potential apphicability of Parratt to intentional deprivations. Indeed, Kimbrough itself contained little reasoned analysis as to why the Parratt-Bonner $I$ interpretation of the fourteenth amendment should not apply to intentional deprivations. The lack of reasoned analysis in Kimbrough is surprising since the Kimbrough court explained that the petition for rehearing en banc was granted so that the views forwarded in the panel opinion, 523 F.2d 1057 (7th Cir. 1975), and in Bonner, 517 F.2d 1311 (7th Cir. 1975) could be considered.

In the Kimbrough panel decision, Judge Cummings, in the lead opinion, concluded without analysis that the plaintiff's complaint, which alleged that a valuable ring taken from him by de- 


\section{Parratt, ${ }^{51}$ as well as the nature of the process that Parratt requires the}

fendant law enforcement officers was not returned to him upon his release from custody, stated a cause of action under $\$ 1983$. 523 F.2d at 1059. In a concurring opinion, Judge Swygert suggested that intentional deprivations implicate substantive due process guarantees. Regardless of the procedures available, reasoned Judge Swygert, substantive due process is violated where state agents "affirmatively [imvoke] the power of the state in a completely arbitrary manner and witlout lawful justification in order to effect the actual deprivation." Id. at 1061. Swygert suggested that "arbitrary" meant "a conscious choice of alternative actions . . . [s]o construed, the term does not comprehend simply negligent actions." $I d$. at 1061 n.4.

In coucludimg that the plaintiff stated a claim under $\$ 1983$, the Tarkowski court incorrectly reasoned that the effect of a given interpretation of the fourteenth ameudinent on $\$ 1983$ warrants a particular interpretation of the amendment itself. By so reasoning, the Tarkowski court confused constitutional guarantee with the means to enforce that guarantee. The fourteentl amendment defines the scope of $\S 1983 ; \S 1983$ does not define the scope of the fourteenth amendment. The Tarkowski court's second argument proved to be no more than a variation of its first. Parratt does not "repeal" $\& 1983$ in cases of intentional deprivations, though under a broad reading of that may be its effect; Parratt inerely defines the scope of due process guarantees. Thus, the Tarkowski court in effect relies solely on a pre-Parratt circuit court opinion.

As Tarkowski demonstrates, post-Parratt lower courts find it difficult to establish a convincing basis for limiting Parratt to negligent deprivations. Indeed, some courts liave not attempted to impose such a limit. In Sheppard v. Moore, 514 F. Supp. 1372 (M.D.N.C. 1981), for example, the plaintiff claimed that defendants intentionally refused to return lis property, which had been seized as part of an investigation that was subsequeutly resolved in plaimtiffs favor. In holding that the plaintiff had failed to state a claim under $\$ 1983$, the Sheppard court concluded that, as the raudoin and unauthorized nature of the allegedly intentional deprivation made a predeprivation hearing impracticable, and as North Carolina provided the plaintiff an "excellent opportunity" to remedy the alleged wrong, its "due process analysis collapses into that used by the Parratt Court .... Id. at 1376-77. The Sheppard court appeared to reserve the possibility that due process guarantees could require predeprivation process where certain types of property were at stake; presumably, absence of such predeprivation process would constitute a per se constitutional violation.

Some courts have sought to address the inental state of the Parratt defendant by distinguishing claims based on procedural due process from claims based on substantive due process. Henderson v. Couuts, 544 F. Supp. 149 (E.D. Va. 1982), is an example of a lower court's extension of Parratt to procedural due process claims for intentional deprivations of nonproperty interests. Henderson involved a $\S 1983$ claim filed by a prisoner who alleged that a police officer had used excessive force in effecting his arrest. The defendant moved for summary judgment, but the district court refused to disiniss. The court distinguished $\S 1983$ claims based on alleged violations of procedural due process from $\S 1983$ claims based on alleged violations of substantive due process, and found Parratt applicable solely to the former category of claims. Addressing the procedural due process claim, the court ruled that Parratt applied to intentional deprivations of nonproperty interests, such as the assault and battery alleged by the plaintiff in Henderson, where such deprivations result from isolated actions taken in violation of state law. The court then found the plaintiff's allegations insufficient to determine whether plaintiff had stated a substantive due process claim, under the substantive due process test set out in King v. Blankenship, 636 F.2d 70, 72-73 (4th Cir. 1980).

Tarkowski, Sheppard, and Henderson differ as to the circunstances under which Parratt should apply to intentional deprivations. Yet the three decisions reflect a concern that Parratt not erase substantive guarantees provided by the due process clause.

51. Eberle v. Baumfalk, 524 F. Supp. 515 (N.D. Ill. 1981), considered the question of Parratt's applicability to negligent deprivations of liberty interests. Eberle involved an arrestet whose $\S 1983$ claim was based largely on the circumstances surrounding his arrest by defendant police officers. Among the counts on whiel a defendant souglit summary judgment was one in which the arrestee alleged that he liad suffered bodily injury as the direct result of the officer's neghigent driving en route to the jail. Drawing "inferential" support from the Parratt plurality's approving 
state to provide. ${ }^{52}$ The plurality's timing argument, however, provides no convincing grounds for limiting Parratt to either negligent deprivations or to deprivations of property interests.

reference to Ingraham v. Wright, Parratt, 451 U.S. at 542, the court found Parratt applicable to sucli a "garden variety personal injury case," and granted defendant's motion. 524 F. Supp. at 519. The court reasoned that as the injury did not result from a state policy or intentional act, a post-deprivation hearing inade available by the state "would arguably be both necessary and sufficient" to provide the arrestee with all process due. Id. at 518.

The issue in Meshkov v. Abington Township, 517 F. Supp. 1280 (E.D. Pa. 1981), was Parratt's applicability to claims alleging negligent deprivations of life. A decedent's father brought a $\$ 1983$ action against five police officers. One of the claims which defendants sought to dismiss alleged that the police officers' neghigence, and the Township's and police chief's failure to adequately train and supervise the officers, resulted in the decedent's suicide during his deteution. The court considered and rejected an argunent that the plaintiff's claim implicated substantive due process guarantees. Id. at 1284-85. Reasoning that a state forum was available to the plaintiff in which to prosecute his negligence claims, and noting that plaintiff's complaint alleged no violation of an established state procedure, the court invoked Parratt to dismiss the plaintiffs § 1983 action. Id. at 1285-86.

In Howse v. DeBerry Correctional Inst., 537 F. Supp. 1177 (M.D. Tenn. 1982), the district court criticized the results reached by the Eberle and Meshkov courts. In refusing to apply Parratt to an alleged intentional deprivation of a liberty interest, the Howse court suggested that the Supreme Court did not intend Parratt to extend beyond negligent deprivations of property interests. The Howse court supported its conclusion by citing the Parratt concurrences of Justices Blackmun and Powell, and by reasoning that extension of Parratt would render $\$ 1983$ meaningless as well as run counter to the purpose of that statute. Neither concurring opimions nor views of the appropriate function of $\$ 1983$, however, appropriately delimit a reading of the fourteenth ameudment on which a majority of the Parratt Justices appear to agree. Thus, the Howse court's criticism of the Eberle and Meshkov results is misplaced.

52. Discussion of what constitutes an adequate remedy under Parratt is outside the scope of this Note. Problems imclude the nature of the process available in state courts, see, e.g., Wakinekona v. Olim, 664 F.2d 708, 714-15 (9th Cir. 1981), cert. granted, 50 U.S.L.W. 3947 (U.S. June 1, 1982) (No. 81-1581) (suggesting that state court civil riglits action not adequate state process under Parratt); Sheppard v. Moore, 514 F. Supp. 1372, 1377-78 (M.D.N.C. 1981) (state judicial process more than adequate to meet Parratt test where plaintiffs had immediate access to state courts for redress, an opportumity for a jury trial, and a potential recovery of punitive daunages); the possibility of immunity for state actors in state courts, see, e.g., Irshad v. Spann, 543 F. Supp. 922, 928-29 (E.D. Va. 1982) (possibility of a sovereign immunity defense for defendant correctional officers in a state court action does not deprive plaintiff of due process in the state courts, and both inmate grievance procedures and counmon law action for detinue constitute appropriate state processes under Parratt); Eberle v. Baumfalk, 524 F. Supp. 515, 518 (N.D. Ill. 1981) (defendant's immunity from suit under state law does not render Parratt inapplicable); Whorley v. Karr, 534 F. Supp. 88 (W.D. Va. 1981) (Parratt would apparently not control if immunity were available to state actor) (dicta); Frazier v. Collins, 538 F. Supp. 603 (E.D. Va. 1982) (court refused to grant summary judgment on basis of Parratt where immunity potentially available for defendant in state action); and the timeliness of the remedial procedures made available by the state, see, e.g., O'Brien v. Board of Educ., 76 Civ. 660 (PNL) (S.D.N.Y. July 1, 1982) (court requires tinnely availability of some means to assess propriety of state actor's action). See also McKenna v. City of Memphis, 544 F. Supp. 415, 419 (W.D. Tenn. 1982) (good faith allegation of damages in excess of Tennessee Tort Claims Act makes state remedy inadequate); Holinan v. Hilton, 542 F. Supp. 913 (D.N.J. 1982) (state statute which bars suits against public entities or employees by prisoners, although allowing sucli prisoners to file administrative claims, may under Parratt simply "reroute a number of routine prison grievances froin the state courts into the federal courts . . .") (dicta). 


\section{a. Mental State}

Under the plurality's timing argument, Parratt logically may extend to include intentional deprivations. The two restraints placed on Parratt by this process argument are that post-deprivation process must compensate the aggrieved individual, ${ }^{53}$ and that predeprivation process must be impracticable. ${ }^{54}$ If negligent deprivations are adjudged compensable, then it follows that intentional deprivations are compensable, although the amount of compensation required to redress intentional deprivations probably should be higher due to the element of culpability involved. Moreover, it is unlikely that it will be "practicable" to provide prior process in cases of intentional deprivations, if such process is "impracticable" in cases of negligent deprivations. Indeed, to the extent that the state actor is aware of the unauthorized nature of his act, and seeks to avoid discovery, it will likely be at least as "impracticable" to forecast the time and place of the deprivation if it is intentional as if it is negligent.

\section{b. Type of Interest}

The timing argument fails to prevent Parratt's extension to nonproperty interests. It is true that pre-Parratt cases which found postdeprivation process constitutional almost exclusively concerned deprivations of property interests..$^{55}$ Nevertleless, as maintained previously in this Section, the plurality's first argument requires only that postdeprivation process must coinpensate the aggrieved individual, and that predeprivation process inust be "impracticable." Clearly, it is as "impracticable" to provide predeprivation process in cases of unauthorized deprivations of nonproperty interests as in cases of unauthorized deprivations of property interests. Whether post-deprivation process may adequately coinpensate an individual deprived of a life or liberty interest is a more difficult question. Arguably, life and liberty interests are as compensable as property interests. It is true that property interests are more easily conceived of as compensable than nonproperty interests protected under the fourteenth amendment, ${ }^{56}$ since property interests are often envisioned as tangible and restorable, in money if not in kind. But courts are experienced in assessimg compensatory damages where nonproperty interests are infringed; this is the

53. Parratt, 451 U.S. at 543-44.

54. Id. at 543.

55. See supra note 42.

56. See, e.g., Haygood v. Younger, 527 F. Supp., 808, 814 (E.D. Cal. 1981) (process would restore the property itself or its functional equivalent in Parratt, but instant case different because "money is not the equivalent of months of one's life spent in prison."); $\mathcal{f}$. Lassiter v. Department of Social Servs., 452 U.S. 18, 27 (1981) (state determination of parental rights works "a unique kind of deprivatiou"). 
gist of most tort suits. To suggest that compensation for deprivation of a life or liberty interest cannot be effected is to deny the validity of an underlying principle of tort law.

\section{B. The Meaning of an Act of the State}

\section{Analysis of the Plurality's Act of the State Argument}

Implicit in the plurality opinion is a second argument, which suggests that the unauthorized act of a state official is not a completed act of the state. ${ }^{57}$ This second argument posits that while the state actor, acting without authorization, acts as "the state," his actions are themselves insufficient to trigger fourteenth amendment protections. Rather, the state actor's conduct represents an embryonic state involvement from which the state may disassociate itself by provision for subsequent state remedial measures. By limiting fourteenth amendment violations to those situations where the state refuses to disassociate itself from the conduct, Parratt's second argument suggests that fourteenth amendment protections apply only to threats posed by governmental authority, and these protections do not extend to threats posed by individuals clothed in, but acting without regard to, the particular dictates of that authority. ${ }^{58}$

There are problems with the plurality's unwillingness to find com-

57. There are two reasons to imply this argument from the plurality's opinion. First, this argument explains a passage drawn by the Parratt plurality from the 1975 appellate court opimion of Bonner v. Coughlin, 517 F.2d 1311, 1319 (7th Cir. 1975) (Bonner I), modified en banc, 545 F.2d 565 (7th Cir. 1976), cert. denied, 435 U.S. 932 (1978). The Parratt plurality suggested that the Bonner $I$ court's analysis "is the proper manner in which to approach a case such as [Parratt]."

451 U.S. at 542. The Bonner $I$ court stated, in part:

It seems to us that there is an important difference between a challenge to an established state procedure as lacking in due process and a property damage claim arising out of the misconduct of state officers. In the former situation the facts satisfy the most literal reading of the Fourteenth Amendment's prohibition against 'State' deprivations of property; in the latter situation, however, even though there is action (under color of) state law sufficient to bring the amendment into play, the state action is not necessarily complete.

517 F.2d at 1319 (emphasis added).

Second, the remaining possible definitions of "the state" conflict with the balance of the plurality opinion. The plurahity clearly could not be viewing the state actor as completely disassociated from "the state," as in such a case no hearing of any sort would be required by the fourteenth amendment. See Shelley v. Kraemer, 334 U.S. 1, 13 (1948) ("TT]he action inhibited by the first section of the Fourteenth Amendment is only such action as may fairly be said to be that of the States. That Amendment erects no shield against inerely private conduct, however discriminatory or wrongful.") On the other hand, if the plurality were to view the state actor as equivalent to "the state," the plurahty's requirement that "some kind of hearing [be provided] . . . before a State finally deprives a person of his . . . interests," Parratt, 451 U.S. at 540, would require reading "deprives" in a manner rejected by the plurality. The plurality implicitly rejected the argument that unauthorized dispossessions effected by state actors fail to "deprive" individuals of protected interests for fourteenth amendment purposes, stating that "the alleged loss, even though negligently caused, amounted to a deprivation." 451 U.S. at 536-37.

58. See generally Fiss \& Krauthammer, The Rehnquist Court, NEw Republic, Mar. 10, 1982, at 14,16 . 
pleted state involvement in the unauthorized act of a state actor. These problems remain despite the requirement that the state provide appropriate mechanisms to disassociate itself from involvement in the deprivation. First, the plurality's view is inconsistent with some prior decisions of the Court. These decisions have held that the unauthorized act of a state actor itself constitutes sufficient state involvement to ground a fourteenth amendment violation. ${ }^{59}$

Second, the plurality's view of "the state" undervalues the preventive function of the due process clause. Where process, in the form of post-dispossession state adjudications, is provided before a state "completes" its involvement in a deprivation, such process merely protects the individual against the possibility that the state will place its imprimatur upon the deprivation without a hearing. Such process fails to protect the individual against either the deprivation itself, or against the embryonic involvement of the state, through the act of the state agent, in the deprivation. Under the plurality's view of state involvement, the due process clause does not so inuch prevent arbitrary acts of the state as prevent arbitrary state approval of arbitrary, embryonic acts of the state. ${ }^{60}$

\section{Implications of the Plurality's Act of the State Argument \\ a. Mental State}

The state definition argument provides a basis for limiting Parratt to negligent deprivations. While the plurality view of "the state" reflects legitimate concerns of federalism that states be offered a first opportunity to police their own employees, the view sweeps too broadly if it insulates both intentional and negligent conduct froin direct federal

59. See, e.g., Home Tel. \& Tel. Co. v. City of Los Angeles, 227 U.S. 278, 286-87 (1913):

[T] he provisions of the Amendment as conclusively fixed . . a are addressed of course to the States, but also to every person whether natural or judicial who is the repository of state power. By this construction the reach of the Amendment is shown to be coextensive with any exercise by a State of power, in whatever form exerted.

See also Iowa-Des Moines Nat'1 Bank v. Bennett, 284 U.S. 239, 246 (1931) ("When a state official, acting under color of state authority, invades, in the course of his duties, a private right secured by the federal Constitution, that right is violated, even if the state officer not only exceeded his authority but disregarded special commands of the state law."); $c f$. Bantam Books, Inc. v. Sullivan, 372 U.S. 58, 68 (1963) ("The acts and practices of the members . . . of the Commission . . . were performed under color of state law and so constituted acts of the State within the meaning of the Fourteenth Amendment.").

Indeed, the plurality view resembles the now discredited doctrine that a finding of state action requires affirmation of state actors' conduct by the highest court of the state. See Barney v. City of New York, 193 U.S. 430 (1904); Snowden v. Hughes, 321 U.S. 1, 17 (1944) (Frankfurter, J., concurring).

60. The plurality view of state involvement also threatens to leave Parratt applicable to equal protection claims. Analysis of the wisdom of applying Parratt outside the due process context is outside the scope of this Note. For the argument that Parratt may apply to equal protection claims, see Kirby, Demoling 14th Amendment Claims to State Torts, 68 A.B.A. J. 167, 171 (1982). 
attention. Although correction and deterrence of negligent conduct by state officials which deprives individuals of protected interests can properly be left to the state in the first instance, this is not true of intentional deprivations effected by state officials.

Federal courts have a responsibility to scrutinize intentional deprivations of protected interests because conduct effecting such deprivations sufficiently involves the state to trigger fourteenth amendment guarantees. There is a line at which the act of a state official sufficiently involves "the state" so as to trigger immediately the protection of the fourteenth amendment, rather than constituting merely an embryonic act of the state from which the state may disassociate itself by provision for adequate remedial procedures. If a state official acts in accordance with established state procedures, for example, any resultant deprivation of a protected interest will intplicate, though not necessarily violate, due process protections. Where a state official intentionally, but without authorization, deprives an individual of a protected interest, there is equally good reason to conclude that the line has been crossed. Once the line is crossed, of course, federal courts inust recognize a section 1983 claim.

The unauthorized intentional misconduct of a state official suggests a failure of the state's employee selection procedures. These procedures, through the use, for example, of employment histories and psychological evaluations, should identify people with a propensity to violate constitutional guarantees. ${ }^{61}$ Indeed, an intentional deprivation committed by a state actor is the foreseeable result of a defective screening, hiring, or training process. Failure of any of these processes attaches sufficient state responsibility for the unauthorized act to warrant the conclusion that "the state," for purposes of the fourteenth amendment, has at least negligently involved itself in the deprivation at issue. In such a case, to give the state the opportunity to remedy the deprivation through state tort procedures is to ignore the inadequacy of the state's imitial screening, hiring, and training procedures. Suclı a result is inappropriate. Honoring the preventive function of the due process clause requires that the state be encouraged not to ignore, but to implement and contmually improve, procedures by which to prevent arbitrary deprivations.

The difficulty with this argument is that it may apply to negligent deprivations as well as intentional deprivations. It is theoretically possible to screen for neghigent as well as intentional misconduct.

Regardless of whether tests can screen out individuals who will be

61. See generally Lester, Babcock, Cassisi \& Brunetta, Hiring Despite the Psychologist's Objections, 7 CRIM. JUST. AND BEHAV. 41 (1980) (discussing psycliological evaluation of police officers). 
negligent, where the state fails to identify the intentional miscreant the state should no longer be able to claim the benefit of Parratt. By failing to -identify officials who subsequently and intentionally violate the rights of others, the state allows its actors to disrupt expectations, generated by the due process clause, that governmental conduct will be fair and impartial. Expectations of impartiality may coexist with negligent behaviour, because neghgent conduct occurs randomly and is directed at no particular individual. But intentional misconduct by a state offcial implies that the state has singled out a citizen for adverse treatment, and fosters feelings of resentment which are absent in cases of neghigent imisconduct.

If, as suggested by this Part, the unauthorized intentional act of a state employee is deemed to constitute state involvement sufficient to trigger the guarantces of the fourteenth anendment, application of Parratt in cases of intentional conduct can only be justified on the basis of the plurality's first argument, that post-deprivation process satisfies the dictates of the due process clause. Section A of this Part analyzed this first argument, and concluded that rejection of the argument was warranted. Here, however, there is an additional reason, apart from those discussed in Section $\mathrm{A}$, for rejecting the argument that post-deprivation process is adequate process. Applied to intentional conduct, Parratt may remove the state's incentive to improve its employee selection processes so as to limit the occurrence of intentional deprivations. ${ }^{62}$

The proposed limitation of Parratt to unauthorized negligent conduct is consistent with the views expressed by Justice Powell in his concurring opimion. ${ }^{63}$ Powell's opimion, however, is narrower in its analytic scope, and his failure to provide significant precedent or analytical support for his position renders his opinion unpersuasive. Powell argues that a deprivation, in a constitutional sense, requires either an intentional act of demial or a deliberate decision not to act to prevent a loss; he did not consider the availability of subsequent state remedial

62. Even where Parratt is applied, states may have some incentive to improve traming, screening, and hiring processes, at least where states have waived sovereign immunity through instituting tort claims acts. The Nebraska State Tort Claims Act, for example, provides for an action against the state, rather than against mdividual defendants. NEB. REv. STAT, $\$ \$ 81-8,215$, 8,223 (1981). Since, lowever, punitive damages are generally unavailable in Nebraska, Miller v. Kingsley, 194 Neb. 123, 230 N.W.2d 472, 474 (1975), Nebraska's imcentive to improve procedures can be questioned. Conceivably, Nebraska could find it financially worthwhile to "buy off' claimants rather than improve procedures.

The Parratt plurality failed to mention that the Nebraska State Tort Claims Act might immunize the Parratt petitioners, as recovery is denied where claims arise with respect to "the detention of any goods or merchandise by any law enforcement officer." NEB. REv. STAT. \$ 81-8,219(b) (Reissue 1981); further, the Act bars recovery resulting from losses incurrcd by state officials acting in "discretionary" capacities. Neb. Rev. Stat. \$ 81-8,219(a) (Reissue 1981).

63. See supra note 13 and accompanying text. 
procedures to be a determinative factor. It remains unclear whether Justice Powell would recognize a section 1983 action where a state actor negligently deprives an individual of a protected interest, even if the state does not make available adequate remedial procedures. Refusal to recognize a section 1983 claim in such a situation ignores the fact that a state's refusal to provide an adequate remedy in cases of negligent deprivations may constitute an intentional act of denial; as the state is free to fashion its own tort law, a state's refusal to provide adequate remedies may constitute a deliberate choice by the state to deny the aggrieved individual a "meaningful opportunity" to challenge the propriety of the state's conduct.

Apart from constitutional considerations, other arguments favor that Parratt's reach be limited to negligent conduct. First, such a limitation avoids erosion of the substantive guarantees of due process without embracing the overly expansive view of substantive due process advocated by some judges. ${ }^{64}$ Conduct beyond negligence is an inherent element of any substantive due process violation; the category of cases in which negligent deprivations implicate substantive due process guarantees appears to be an empty one. ${ }^{65}$ The proposed limitation on Parratt thus leaves every complamant with a potential claim based on alleged violation of substantive due process rights with a section 1983 cause of action. The complainant inust still demonstrate, however, that the conduct at issue, in the traditional language of substantive due process jurisprudence, "shock[s] the conscience." 66 Negligence, witlout an element of moral culpability, may be subject to disapproval, but cannot in itself shock the conscience of a court.

Second, limitation of Parratt also accommodates policy considerations concerning the appropriate function of section 1983 and the effect of section 1983 on a burgeoning federal caseload. Limiting Parratt to negligent deprivations reserves the section 1983 action as a meclianism for deterrence of official misconduct ${ }^{67}$ that takes the form of unauthorized intentional conduct by a state actor, or that takes the form of an imprimatur intentionally placed by the state on the unauthorized negli-

64. See supra note 50 .

65. Whirl v. Kern, 407 F.2d 781 (5th Cir. 1969), is incorrectly interpreted if viewed as a case in which negligent conduct founded a substantive due process claim under $\S 1983$. Whirl involved a sheriff who, never having been told that charges against plaintiff had been dismissed, kept plaintiff in custody for several months. Although defendant sheriff had acted reasonably, according to a finding by the jury, the plaintiff was held to have stated a $\$ 1983$ claim. Whirl did involve intent, lowever, as the slieriff intended the confinement of the plaintiff, despite his belief in the legality of that confineinent. $C f$. Haygood v. Younger, 527 F. Supp. 808 (E.D. Cal. 1981) (defendant's miscalculation of plaintiff's sentence, which led to plaintiff spending excess time in prison, could deprive plaintiff of constitutional rights).

66. Rochin v. California, 342 U.S. 165, 172 (1952).

67. See Monroe v. Pape, 365 U.S. at 172-83. 
gent conduct of a state actor. It is precisely this sort of intentional conduct that arguably leaves the complamant feeling that he has been unfairly treated by the state. ${ }^{68}$ Further, to the extent that a possible function of section 1983 is to provide a psychological safety valve, by allowing the disgruntled individual a forum for complaint, this function is largely satisfied by limiting Parratt to negligent conduct. The limitation also removes from the federal caseload that large number of complaints which allege no more than negligent unauthorized conduct by state actors, and which thus do not require the attention of federal courts. ${ }^{69}$

\section{b. Types of Interests}

The state involvement argument does not require that Parratt be restricted to property interests. The argument focuses on when the state may be said to be so involved in a deprivation that state action is complete. Under this argument, the deprivation itself is completed prior to the process afforded by the state; it is the involvement of the state $\mathrm{m}$ the deprivation that remams incomplete. Such an argument does not distimguish among types of imterests.

Arguably, life or hiberty deprivations effected by state actors differ in kind from similar deprivations effected by private individuals. ${ }^{70}$ Deprivations effected by state actors, particularly deprivations of life or liberty interests, may appear particularly repugnant. ${ }^{71}$ But to the extent that such deprivations are more repugnant than deprivations of property, they will more likely fall witlim substantive due process protection. $^{72}$

By restricting Parratt to negligent deprivations, as proposed in this Note, claims alleging substantive due process violations will not be dismissed on the basis of Parratt, since intent appears to be an inherent requirement im any substantive due process claim. Indeed, claims which allege intentional deprivations of life or liberty interests, but which do not implicate substantive due process guarantees, will not be dismissed on the basis of Parratt if the proposal in this Note is followed. By extending Parratt's reach to life and liberty imterests, while limiting its use to negligent conduct, Parratt will reach no more than the "garden variety" life, liberty, or property claim.

68. See supra pages $275-76$.

69. Federal courts will of course be responsible for assessing the adequacy of state remedial procedures. Yet, after an initial period, such assessment will not likely require case-by-case analysis, thus permitting a reduction in the $\S 1983$ caseload in the federal courts.

70. It is im this sense, perhaps, that valid arguments niay be inade as to the noncoinpensability of deprivations effected by state actors. See supra note 56 and accompanying text.

71. See supra note 51 .

72. Holmes v. Wainpler, 546 F. Supp. 500, 503 (E.D. Va. 1982). 


\section{CONCLUSION}

Parratt v. Taylor addresses the question of whether unauthorized conduct by state actors which effects deprivations of interests protected under the fourteenth amendment should receive direct federal attention under section 1983, where states demonstrate willingness to provide process in the form of subsequent adjudicatory procedures. This Note demonstrates that the Parratt Court's solution to this question rests on two independent arguments. The first argument posits that post-deprivation process is constitutionally satisfactory where predeprivation process is "impracticable." Such an argument leaves no principled grounds for limiting Parratt to its facts. Indeed, courts accepting such an argument should extend Parratt to intentional mental states and to nonproperty interests. The second argument posits that "the state," for fourteenth amendment purposes, is not acting until such time as the state refuses to make available post-deprivation process to an aggrieved individual. Courts which choose this argument may limit the reach of Parratt to neghigent deprivations, but should continue to recognize section 1983 actions where intentional, reckless, or grossly negligent conduct is alleged. The second argument, however, does not provide convincing grounds for limiting Parratt to property interests.

Thus, courts concerned with preserving section 1983 actions in instances of intentional misconduct by state officials may do so without violating any directive imposed by Parratt. By doing so, courts may avoid responding inconsistently to Supreme Court directive, may prevent erosion of substantive due process guarantees, and may preserve section 1983 actions for those cases that directly concern governmental misconduct and that directly or indirectly implicate the adequacy of established state procedures.

Daniel Steiner*

* B.A. 1977, Yale University; third-year student, Boalt Hall School of Law, University of California, Berkeley. 